\title{
PALEOENVIRONMENT IN DAE-AM SAN HIGH MOOR IN THE KOREAN PENINSULA
}

\author{
T Yoshioka ${ }^{1,2} \bullet \mathrm{J}-\mathrm{YLe}^{1} \bullet \mathrm{H}$ A Takahashi ${ }^{3}$ S-J Kang ${ }^{4}$ \\ ABSTRACT. We discuss paleoenvironmental changes at the Dae-Am San high moor, located near the Demilitarized Zone at \\ $38^{\circ} \mathrm{N}$. This area has been reported to be the only high moor in the Korean peninsula. The ${ }^{14} \mathrm{C}$ age of the bottom sediment $(75-$ \\ $80 \mathrm{~cm}$ in depth) at this site is about 1900 BP. Since the radiocarbon ages for the intervals at 50-55 cm and $75-80 \mathrm{~cm}$ were \\ almost the same, we conclude that the deep layers $(55-80 \mathrm{~cm})$ in the high moor were all part of the original soil. Low organic \\ $\mathrm{C}$ and $\mathrm{N}$ contents in the deeper layers support this inference. The 50-55-cm layer consists of sandy material with very low \\ organic content, suggesting erosion from the surrounding area. The surface layer $(0-5 \mathrm{~cm})$ was measured as $190 \mathrm{BP}$, and the \\ middle layer $(30-35 \mathrm{~cm})$ was $870 \underline{\mathrm{BP}}$. The bulk sedimentation rate was estimated to be about $0.4 \mathrm{~mm} \mathrm{yr}^{-1}$ for the $0-30-\mathrm{cm}$ \\ interval. The $\delta^{13} \mathrm{C}$ value of organic carbon in the sediments fluctuated with depth. The $\delta^{13} \mathrm{C}$ profile of the Dae-Am San high \\ moor may be explained by climatic changes which occurred during the Little Ice Age and Medieval Warm Period.
}

\section{INTRODUCTION}

Terrestrial paleoenvironments can be reconstructed using sediment cores from lakes and swamps (e.g. Williams et al. 1997). The Dae-Am San Yong-Nup (high moor) on Dae-Am San Mountain is located near $38^{\circ} \mathrm{N}$ latitude, in the Demilitarized Zone (DMZ). This site is believed to be the only high moor in the Korean Peninsula. The paleoenvironmental reconstruction of this high moor reflects on the broader environmental changes which occurred in the Korean Peninsula during its formation. In this study, we analyzed the sediment carbon isotopic compositions from the Dae-Am San high moor and assessed possible environmental changes reflected in the record.

\section{METHODS}

Dae-Am San high moor (area $=3.15$ ha) is located on the north-facing slope of Mount Dae-Am $\left(128^{\circ} 07^{\prime} \mathrm{E}, 38^{\circ} 13^{\prime} \mathrm{N}\right)$ at an elevation between 1100 and $1200 \mathrm{~m}$. Although at the deepest point the peat soil was deeper than $150 \mathrm{~cm}$, the site where the samples were collected accumulated peat for less than $80 \mathrm{~cm}$ of its depth. Sediments were collected in 15 layers of $5-\mathrm{cm}$ thickness from 0 to $80 \mathrm{~cm}$ depth, except for the 60-70-cm layer. Samples were air-dried and sieved with 500 and $250 \mu \mathrm{m}$ mesh stainless steel sieves, and weighed to calculate the relative abundance (Figure 1). Three sizes of the sieved samples $(<250 \mu \mathrm{m}, 250-500 \mu \mathrm{m}$, and $>500 \mu \mathrm{m})$ were treated by a sealed-quartz-tube combustion method (Minagawa et al. 1984) for carbon and nitrogen isotope measurements. During the gas purification procedure, the organic carbon (Org. C) and total nitrogen (TN) contents were estimated from the barometric measurements of $\mathrm{CO}_{2}$ and $\mathrm{N}_{2}$ gases produced from the sample. Since the differences in Org. C, TN and isotope ratio among sizes were small, Org. C and TN contents and carbon isotope ratios for each layer were calculated from the size fractions using relative abundances. The ${ }^{13} \mathrm{C}$ isotopic compositions were measured with an isotope ratio mass spectrometer (MAT 252, Thermoquest, Ltd.). These isotopic ratios are expressed with $\delta$ notation (unit $=\%$ ). The ${ }^{14} \mathrm{C}$ content was determined for the $>500-\mu \mathrm{m}$ fractions from five layers $(0-5 \mathrm{~cm}, 30-35 \mathrm{~cm}, 45-50 \mathrm{~cm}, 55-60 \mathrm{~cm}$, and $75-80 \mathrm{~cm}$ ). The samples were treated using an acid-alkali-acid (AAA) treatment sequence of $\mathrm{HCl}$ $(1.2 \mathrm{~N}), \mathrm{NaOH}$ solution $(1.2 \mathrm{~N}), \mathrm{HCl}(1.2 \mathrm{~N})$, to remove organic contaminants. The treated samples containing carbon of about $2 \mathrm{mg}$ was combusted to $\mathrm{CO}_{2}$ at $850{ }^{\circ} \mathrm{C}$ for $2 \mathrm{hr}$ in a vacuum-sealed Vycor

\footnotetext{
${ }^{1}$ Institute for Hydrospheric-Atmospheric Sciences, Nagoya University, Nagoya 464-8601, Japan

${ }^{2}$ Present address: Research Institute for Humanity and Nature. Kyoto 606-8502, Japan. Email: yos@chikyu.ac.jp.

${ }^{3}$ Department of Earth and Planetary Sciences, Graduate School of Science, Nagoya University, Nagoya 464-8602, Japan

${ }^{4}$ Department of Science Education, Chungbuk National University, Chongju, Chungbuk-do, Korea
}

(C) 2001 by the Arizona Board of Regents on behalf of the University of Arizona RADIOCARBON, Vol 43, Nr 2B, 2001, p 555-559

Proceedings of the 17 th International ${ }^{14} \mathrm{C}$ Conference, edited by I Carmi and E Boaretto 
tube with $\mathrm{CuO}$. The cryogenically purified $\mathrm{CO}_{2}$ gas was reduced to graphite with hydrogen gas (Kitagawa et al. 1993). The graphite targets prepared from a sample and a standard of NBS oxalic acid (RM-49), were used for ${ }^{14} \mathrm{C}$ analysis with a Tandetron Accelerator Mass Spectrometer at the Center for Chronological Research in Nagoya University. The isotopic fractionation was corrected using the sample $\delta^{13} \mathrm{C}$ value in evaluation of the ${ }^{14} \mathrm{C}$ age.

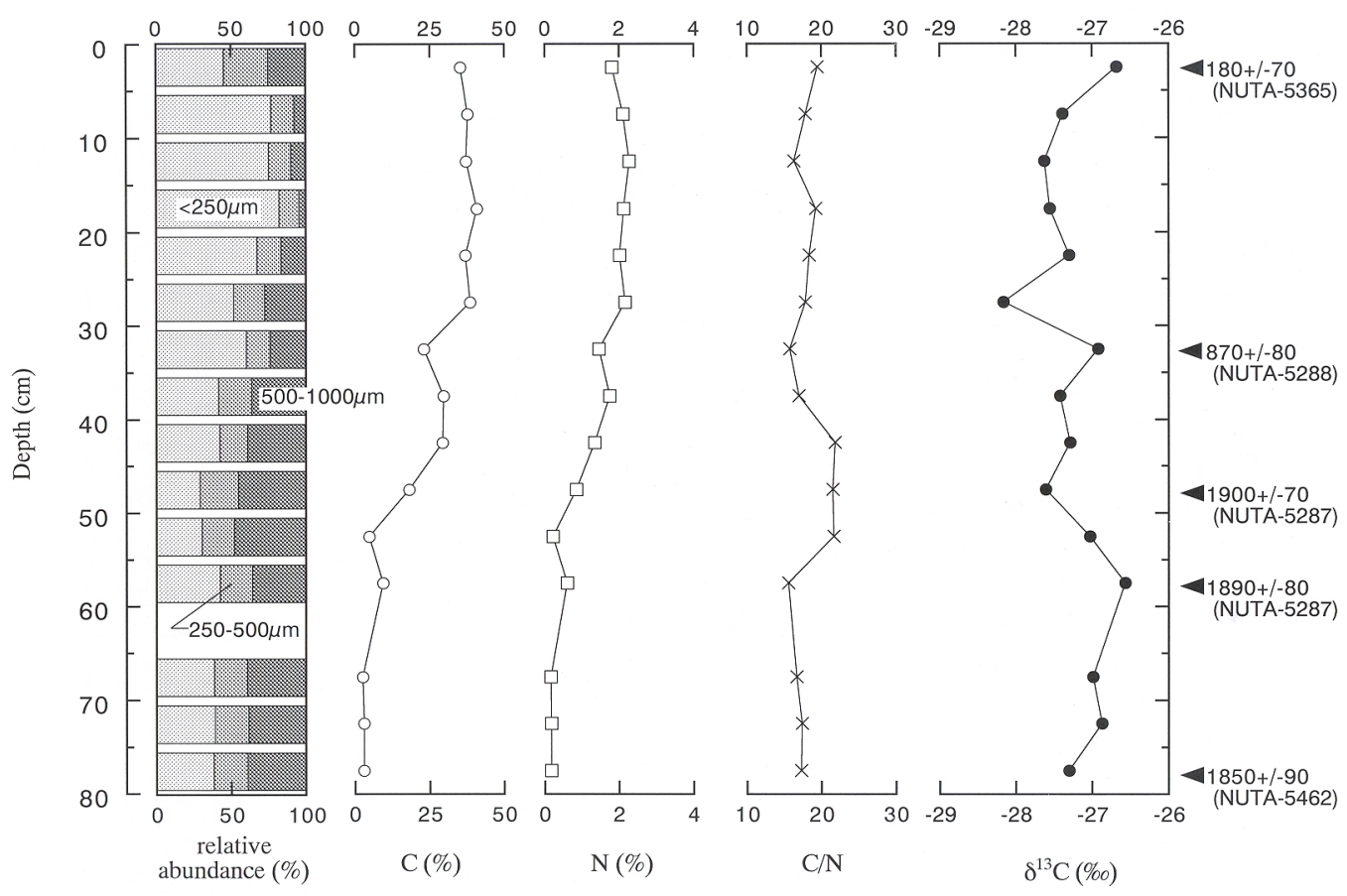

Figure 1 Vertical distributions of relative abundance of size fractions (bars), organic carbon (open circle) and total nitrogen contents (open square), $\mathrm{C} / \mathrm{N}$ ratio (X), and carbon (closed circle) isotope ratios of the sediments in Dae-Am San high moor, Korea. Measured ${ }^{14} \mathrm{C}$ ages (yr BP $\pm 1 \sigma$ ) were indicated at the right-hand side.

\section{RESULTS}

Organic carbon (Org. C) and total nitrogen (TN) contents in the sediments varied with depth (Figure 1). Both contents were higher in the surface layers $(<30 \mathrm{~cm})$. Org. C and TN ranged from 35 to $41 \%$ and from 1.8 to $2.3 \%$, respectively. From 30 to $55 \mathrm{~cm}$, they decreased sharply, with a small maximum in the $35-40 \mathrm{~cm}$ layer. There was also a small maximum both in carbon and nitrogen contents in the 55-60 cm layer. Organic contents between 60 and $80 \mathrm{~cm}$ were as low as $3 \%$ carbon and $0.2 \%$ nitrogen. In spite of the large variations in Org. $\mathrm{C}$ and $\mathrm{TN}$, the weight to weight ratio between them $(\mathrm{C} / \mathrm{N})$ was rather constant (average, $18.3 \pm 2.1, \mathrm{n}=15$, Figure 1 ).

The $\delta^{13} \mathrm{C}$ values of the bulk sediment ranged from -28.2 to $-26.6 \%$, with minima $(<-27.5 \%$ ) at 10 $15 \mathrm{~cm}, 25-30 \mathrm{~cm}$, and $45-50 \mathrm{~cm}$ layers (Figure 1). The deepest layer also showed a low $\delta^{13} \mathrm{C}$ value.

Table 1 shows the results of the ${ }^{14} \mathrm{C}$ dating. The $0-5 \mathrm{~cm}$ and $30-35 \mathrm{~cm}$ layers exhibited the age of $180 \pm 70 \mathrm{BP}$ and $870 \pm 80 \mathrm{BP}$, respectively. All three layers deeper than $45 \mathrm{~cm}$ showed a similar age of about $1900 \mathrm{BP}$. 
Table 1 Radiocarbon ages of Dae-Am Sang high moor sediments

\begin{tabular}{|c|c|c|c|c|}
\hline \multirow[b]{2}{*}{ Layer $(\mathrm{cm})$} & \multirow{2}{*}{$\begin{array}{c}{ }^{14} \mathrm{C} \text { age } \\
(\mathrm{BP})\end{array}$} & \multicolumn{2}{|c|}{ Calibrated age } & \multirow{2}{*}{$\begin{array}{l}\text { Lab code } \\
\text { (NUTA-) }\end{array}$} \\
\hline & & Cal AD & Probability & \\
\hline $0-5$ & $180 \pm 70$ & $\begin{array}{l}1654-1697 \\
1725-1815 \\
1841-1874 \\
1918-1944\end{array}$ & $\begin{array}{l}0.201 \\
0.482 \\
0.160 \\
0.157\end{array}$ & 5365 \\
\hline $30-35$ & $870 \pm 80$ & $\begin{array}{l}1046-1091 \\
1119-1139 \\
1154-1240\end{array}$ & $\begin{array}{l}0.296 \\
0.117 \\
0.587\end{array}$ & 5288 \\
\hline $45-50$ & $1900 \pm 70$ & $\begin{array}{c}31-37 \\
51-179 \\
189-213\end{array}$ & $\begin{array}{l}0.055 \\
0.836 \\
0.109\end{array}$ & 5287 \\
\hline $55-60$ & $1890 \pm 80$ & $55-230$ & 1.000 & 5364 \\
\hline $75-80$ & $1850 \pm 90$ & $\begin{array}{r}64-257 \\
300-321\end{array}$ & $\begin{array}{l}0.929 \\
0.071\end{array}$ & 5462 \\
\hline
\end{tabular}

${ }^{\text {a The }}{ }^{14} \mathrm{C}$ ages were converted to calibrated ages using the INTCAL98 program, Calib 4.1.2 downloaded from the website of the University of Washington Quaternary Isotope Lab. URL: <http://depts.washington.edu/qil/dloadcalib/>. Accessed 9 Feb 2000.

\section{DISCUSSION}

Since the Org. C contents at the $55-60 \mathrm{~cm}$ layer was as high as $10 \%$, the swamp might have been initiated at the 50-cm depth, which corresponds to about $1900 \mathrm{BP}$. Assuming that the accumulation rate of peat between layers was constant, the bulk sedimentation rate was about $0.4 \mathrm{~mm} \mathrm{yr}^{-1}$ for the surface 35-cm layers, and about $0.15 \mathrm{~mm} \mathrm{yr}^{-1}$ for the 35-50-cm layers. Estimated ages for each layer are shown in Figure 2. The range of bulk sedimentation rate is similar to the sedimentation rate in the Ozegahara wetland in Japan (Minomo et al. 1997).

Plant $\delta^{13} \mathrm{C}$ values reflect a changing ecosystem through time. In Dae-Am San high moor, the vegetation changed from sedge to sphagnum during swamp development (Environmental Agency, Korea, 1988). Some of the observed $\delta^{13} \mathrm{C}$ variations shown in Figure 1 may be due to vegetation changes (White et al. 1994). Another factor affecting the $\delta^{13} \mathrm{C}$ value of peat is the selective decomposition of organic carbon. Since lignin has a lower $\delta^{13} \mathrm{C}$ value than polysaccharides, the preferential loss of polysaccharides, such as hemicellulose and cellulose, may cause a decrease in bulk organic carbon $\delta^{13} \mathrm{C}$ values (Benner et al. 1987). Minomo et al. (1997) suggested that the low $\delta^{13} \mathrm{C}$ value in the deep layer of Ozegahara peat sediment indicated an increase in lignin content. The analysis of environmental changes in a swamp from the isotopic viewpoint, thus, is complicated. However, the vertical changes in the isotopic compositions obtained here would indicate some environmental changes in the Dae-Am San high moor and also in the Korean Peninsula, because the $\delta^{13} \mathrm{C}$ value fluctuated with depth.

Recently, much attention has been paid to the Little Ice Age (LIA) and Medieval Warm Period (MWP). The paleoclimate changes in the last 2000 to $3000 \mathrm{yr}$ have been studied in ice cores and marine sediments (e.g. Kreutz et al. 1997; Keigwin 1996). The $\delta^{13} \mathrm{C}$ records preserved in tree rings of Japanese cedar in Yakushima Island indicated a relatively cold climate from AD 610 to 700 and from AD 1580 to 1700 (Kitagawa and Matsumoto 1995). The latter period was related to LIA. Dur- 
ing AD 700-1200 (corresponding to MWP), about $1{ }^{\circ} \mathrm{C}$ increase in average temperature was estimated from tree ring analyses (Kitagawa and Matsumoto 1995).

Upward increases in the $\delta^{13} \mathrm{C}$ values (Figure 1) from 50 to $35 \mathrm{~cm}$ and from 15 to $0 \mathrm{~cm}$ suggest increasing temperatures and/or dry conditions. During these periods, the Dae-Am San high moor developed. The ages of the layers, where the $\delta^{13} \mathrm{C}$ minima of sedimentary organic matter were found in Dae-Am San high moor (Figure 1), correspond to about 400, 750, and $1200 \mathrm{yr}$ ago (Figure 2). The maximum $\delta^{13} \mathrm{C}$ values occurred in the layer with an estimated age of about $900 \mathrm{BP}$. The sedimentary $\delta^{13} \mathrm{C}$ records in Dae-Am San high moor suggest that the climate in the Korean Peninsula was cold in the LIA and about $1200 \mathrm{yr}$ ago, and warm during the MWP. This suggests that the main cause of $\delta^{13} \mathrm{C}$ variations could have been initiated by changes in air temperature. If this is true then the Little Ice Age and Medieval Warm Period are global events, affecting the swamp environment in the Korean Peninsula. However, water conditions must also be considered. Since there is no information on cold climate about $750 \mathrm{yr}$ ago, the abrupt decrease in the $\delta^{13} \mathrm{C}$ value in the $25-30-\mathrm{cm}$ depth range could indicate a change in water supply at that time.

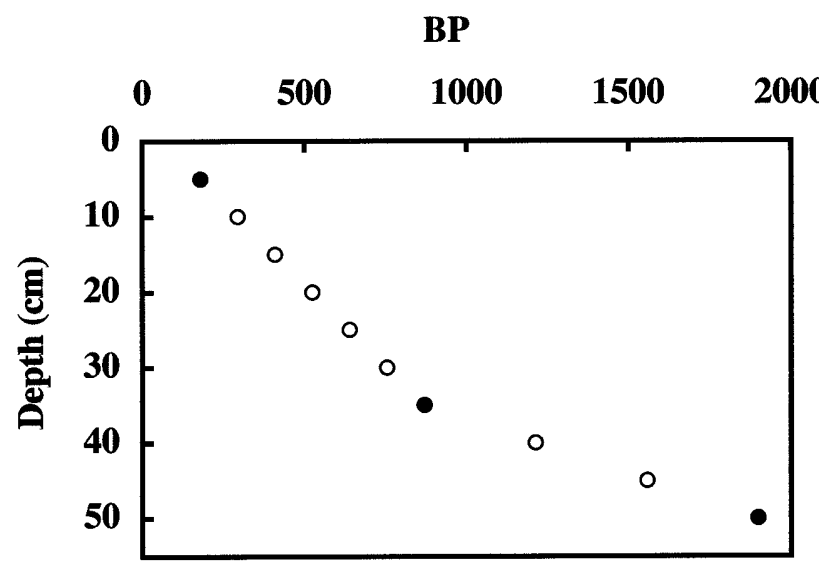

Figure 2 Estimated ages for the layers from 0 to $50 \mathrm{~cm}$ depth. The constant accumulation rates were assumed between layers (closed circles) of which radiocarbon age were measured.

\section{ACKNOWLEDGMENT}

The authors thank Dr K Kato, Institute for Hydrospheric-Atmospheric Sciences, Nagoya University, and Dr T Nakamura, Center for Chronological Research, Nagoya University, for their kind help in this study. This study was partly supported by JSPS, an international bilateral cooperation program.

\section{REFERENCES}

Benner R, Fogel ML, Sprague EK, Hodson RE. 1987. Depletion of ${ }^{13} \mathrm{C}$ in lignin and its implications for stable carbon isotope studies. Nature 329:708-10.

Environmental Agency, Korea. 1988. Report on the research of the natural ecosystem in Dae-Am mountain. 230 p. In Korean.

Keigwin LD. 1996. The Little Ice Age and Medieval Warm Period in the Sargasso Sea. Science 274:1504-8.

Kitagawa H, Masuzawa T, Nakamura T, Matsumoto E. 1993. A batch preparation method for graphite targets with low background for AMS ${ }^{14} \mathrm{C}$ measurements. $R a$ diocarbon 35(2):295-300.

Kitagawa H, Matsumoto E. 1995. Climatic implications of $\delta^{13} \mathrm{C}$ variations in a Japanese cedar Cryptomeria japonica during the last two millenia. Geophysical Research Letters 22:2155-58.

Kreutz KJ, Mayewski PA, Meeker LD, Twickler MS, Whitlow SI, Pittalwala II. 1997. Bipolar changes in atmospheric circulation during the Little Ice Age. Science 277:1294-6. 
Minagawa M, Winter DA, Kaplan IR. 1984. Comparison of Kjeldahl and combustion methods for measurement of nitrogen isotope ratios in organic matter. Analytical Chemistry 56:1859-61.

Minomo K, Akagi T, Yonemura S, Yoh M, Turuta H, Nakamura T. 1997. $\delta^{13} \mathrm{C}$ vertical change of peat in the Ozegahara wetland. Summaries of Researches Using AMS at Nagoya University (III). Dating and Materials Research Center, Nagoya University. p 146-51. In Japanese with English abstract.
White JWC, Ciais P, Figge RA, Kenny R, Markgraf V. 1994. A high-resolution record of atmospheric $\mathrm{CO}_{2}$ content from carbon isotopes in peat. Nature 367:1536.

Williams DF, Peck J, Karabanov EB, Prokopenko AA, Kravchinsky V, King J, Kuzmin MI. 1997. Lake Baikal record of continental climate response to orbital insolation during the past 5 million yrs. Science 278:1114-7. 